\title{
Improving Safety in the Medicines Use Process for Disabled Persons in Residential Facilities. Results from a Pilot Study
}

Linda Aagaard Thomsen ${ }^{1^{*}}$, Charlotte Rossing ${ }^{1}$, Hans Trier $^{2}$, Mette Faber ${ }^{3}$ and Hanne Herborg ${ }^{1}$

${ }^{1}$ Pharmakon, Danish College for Pharmacy Practice, Denmark

${ }^{2}$ Danish Society for Patient Safety, Denmark

${ }^{3}$ Director of Department of Integrated Health Care, Bispebjerg Hospital, Denmark

"Corresponding author: Linda Aagaard Thomsen, Head of R\&D department

Pharmakon, Danish College for Pharmacy Practice, Denmark; Tel: +45 4820 6379; E-mail: lat@pharmakon.dk

Rec Date: Feb 21, 2014, Acc Date: May 29, 2014, Pub Date: May 31, 2014

Copyright: @ 2014 Thomsen LA, et al. This is an open-access article distributed under the terms of the Creative Commons Attribution License, which permits unrestricted use, distribution, and reproduction in any medium, provided the original author and source are credited.

\begin{abstract}
Background: Persons with severe disability often require long-term or life-long placement in residential facilities. Although they often need complex medical treatment, most residential facilities in Denmark do not have staff with health care training.
\end{abstract}

Objective: To improve knowledge on medication safety issues in residential facilities for persons with severe disability (mental illness or physical / intellectual disability) and to test if two clinical pharmacy services could be delivered to residential facilities by community pharmacies in order to improve safety.

Setting: Four residential facilities with 47 residents and a pharmacist from the four community pharmacies delivering medicines to these facilities.

Method: The pilot study aimed at development and assessment of feasibility of an intervention with two pharmaceutical care services: a quality improvement service supporting the residential facility in quality development of routines for handling medicines, and a pharmaceutical care oriented 'medicines care' service aimed at quality improvement of residents' medication therapy. The 'medicines care' service included a technical medication review conducted by a community pharmacist, a 'medicines care' meeting at the residential facility, and if needed, a 'multidisciplinary medicines management conference'.

Main outcome measure: Number of completed services, characteristics of and solutions to identified medication therapy problems, suggested changes to routines for handling medicines and implementation thereof, the involved actors' satisfaction with the intervention, and rated changes in staff's knowledge and self-efficacy.

Results: The quality improvement service resulted in 45 suggestions for changes towards safer routines for handling medicines, mostly concerning administration of medicines. Sixty-six medication therapy problems were identified in 30 of the 47 residents receiving the 'medicines care' service. Adverse drug reactions were the most frequent problems (31.8\%). Of the 50 suggestions for solving medication therapy problems, 14 were implemented by the facilities, whereas 36 required involvement of the prescriber. The prescribers gave feedback on 22 suggestions of which they accepted 19 (86.4\%). One multidisciplinary medicines management conference was conducted.

Conclusion: The study generated important knowledge on safety issues in residential facilities, and revealed a number of medication therapy problems for the residents. The pharmaceutical care services were implementable and demonstrated a potential to improve safety, but this has to be confirmed in a larger prospective trial.

Keywords: Health care; Health promotion; Hental and intellectual disabilities; Hedication safety issues

\section{Impact of findings}

- Medication therapy problems occur frequently in residents with severe mental illness or physical or intellectual disability living in residential facilities.

- Pharmaceutical care services aimed at quality improvement of staff's administration of medicines and residents' use of medicines can be delivered by community pharmacists and have the potential to improve safety.

- There may be a need for development of an educational program aimed at safe medication practices for staff in residential facilities without health care training.

\section{Introduction}

The United Nations' Convention on the Rights of Persons with Disabilities establishes the rights to health and health care for persons with disabilities [1]. However, studies have shown that inequalities 
exist in health care on the basis of disability, such as unmet health care needs, inadequate focus on health promotion, and inadequate access to quality health care and preventive services [2-5].

According to the convention of the United Nations, the term disability includes persons with long-term physical, mental, intellectual or sensory impairments which, in interaction with various barriers, may hinder their full and effective participation in society on an equal basis with others. In Denmark, approximately $1 \%$ of the population has an intellectual disability, and $8 \%$ a mental illness. Severe disability often requires long-term or life-long placement in a residential facility. In Denmark, approximately 14,000 disabled persons reside in such facilities permanently or temporarily. Persons with mental and intellectual disabilities constitute the largest group of residents in such facilities (56\%) followed by the group of residents with severe mental illnesses (25\%) [6,7].

The health status of persons with severe disability is of major concern due to a number of associated, comorbid or secondary conditions which require intensive and complex medical care. Many develop somatic diseases such as cardiovascular disease, type-2 diabetes, chronic obstructive pulmonary disease or cancer at a much earlier age than the general population [5,8-10]. Additionally, it is challenging to determine the positive and adverse effects of a medical treatment particularly in persons with intellectual disability. Their pharmacological responses to medicines may differ from the general population's, and their reactions towards adverse drug reactions may be anxiety or aggressive behavior [11]. Due to limited resources, the disabled depend on competent caregivers. It is therefore a challenge that most staff in Danish residential facilities does not have a background in health care. The management is responsible for the necessary training of the staff that administer medicines, but the necessary training is often not available or is perceived as inadequate for residential facilities [12].

Medication errors, defined as failures in the treatment process that lead to or have the potential to lead to harm to the patient, have often been documented in residential facilities [13]. Such errors may be due to the under- and overuse of medicines or medicines not being handled according to regulations and standards. The overuse of antipsychotics and benzodiazepines has often been described and is often debated in the media [3,4,14-18]. The consequences of such medication errors are fairly unknown. It has been demonstrated that severe mental illness is associated with increased mortality, but it is uncertain whether medication errors contribute to the mortality rate $[19,20]$.

Few studies describe interventions aimed at increasing safety in medicines use in residential facilities for the disabled. A literature review provided some evidence that pharmacist- conducted medication review, treatment monitoring and counselling may improve adherence and reduce inappropriate medicines use [21]. Similar clinical pharmacy services have been extensively tested in a large number of studies in nursing homes. These studies demonstrated how medication reconciliation, medication review and quality improvement of staffs routines for administering medicines result in a better disease management and better patient outcomes, as well as an increase in staff s knowledge and self-efficacy [21-30]. Therefore, such services may be adapted to provide similar results in residential facilities for the disabled.

\section{Aim of the study}

The aim of this pilot study was to 1) improve knowledge on medication safety issues in residential facilities for the disabled, and 2) test if existing clinical pharmacy services can be adapted and delivered to residential facilities by community pharmacies in order to improve medication safety.

\section{Method}

\section{Organization of the study}

The study group consisted of representatives from Disabled Peoples Organisations in Denmark, the Association of Danish Pharmacies, the Danish Society for Patient Safety, Pharmakon - Danish College of Pharmacy Practice, and the two participating municipalities. The study group was responsible for conducting the study according to the study protocol.

\section{Study design and study population}

This study relied on previous development and addressed the second step of the framework for the development and evaluation of complex interventions, which is the assessment of feasibility and piloting of methods [31]. Accordingly, the study was formative (learning-oriented) and explorative, aiming at developing a feasible intervention and revealing quality assessment categories relevant for a subsequent larger study. The intervention consisted of two pharmaceutical care services delivered by community pharmacies $[32,33]$.

A quality improvement service supporting the residential facility in the quality development of routines for handling medicines - that is ordering, receiving, storing, dispensing, administering, documenting and disposing of medicines.

A pharmaceutical care-oriented medication review service aimed at the quality improvement of residents' medication therapy.

The intervention was tailored to meet the needs of the residential facilities through task and learning analyses with staff and management at each participating facility[34]. The tasks related to medicines and needs for learning identified by staff were used for targeting the intervention and for training the participating pharmacists.

Four residential facilities were asked to participate in the study. All four agreed to participate and assigned three to six staff members to the study. The facilities were selected based on convenience sampling. Two facilities were for persons with severe mental illnesses, and two for persons with physical and/or intellectual disabilities. The four community pharmacies delivering medicines to these facilities also agreed to participate in the study.

The staff of the facilities invited residents to participate in the study. The inclusion criteria were that the residents used medicine, and that staff was responsible for administering medicine to the residents. An exclusion criterion was that participation would cause anxiety or stress. The residents (or their guardians) were informed about the study by the facility both orally and in writing.

The community pharmacists received a mandatory three-day course prior to the study period. The course concerned the handling of medicines in residential facilities, medical treatment of relevant 
diseases and conditions, communication skills, and how to conduct the two services. The study group supported the pharmacists with individual oral feedback on their performance, based on the service delivery documentation continuously submitted by the pharmacists to the study group.

The Danish Data Protection Agency granted permission to conduct the study. All participating residents or their guardians gave informed consent to participate in the study and permission for the pharmacist to receive information about their medicines use. No further ethics approval was needed.

\section{Delivery of the two pharmaceutical care services}

A standard operation procedure was developed for both services by the study group. The standard operating procedure described the aim and background of the service and gave instructions on how to deliver the service and the necessary documentation.

\section{The quality improvement service}

This quality improvement service took place at institutional level. The aim of the service was to ensure that the residential facility handled medicines safely and in compliance with the legislation. The outset was an audit of existing routines for handling medicines in the facility in order to expose the needs for quality improvement. The content and focus of the audit followed the audits conducted by the Danish Health and Medicines Authority. The pharmacist conducted the audit by reading the facility's instructions on medicines, observing how staff handled medicines within all stages of the medicines use process, and by performing structured interviews with staff and management. The pharmacist then prepared an audit report describing where quality improvement was needed and possible solutions, and presented the report to the management of the facility.

\section{Medication review as a "medicines care" service}

The aim of the service was to improve the quality of the individual resident's medicines use. The review process included the following steps:

A "technical medication review" conducted by the community pharmacist.

A "medicines care" meeting at the residential facility with the pharmacist and staff responsible for the resident's medication. The resident participated if capable thereof.

A "multidisciplinary medicines management conference". If considered necessary, the residential facility arranged a conference with above persons as well as the general practitioner, specialists and relatives.

The technical medication review was a structured review of the resident's medicines list using national therapy guidelines and drug formulary, in order to identify potential medication therapy problems (MTPs). The technical review was conducted by using the procedure of the Association of Danish Pharmacies and served as the pharmacist's preparation for the "medicines care meeting". MTPs were categorized according to Strand et al. [35].

The "medicines care" meeting took place at the residential facility. The participants discussed possible MTPs based on the results from the "technical medication review" and the residents' state of health, symptoms, preferences and effects of implemented treatment. The idea was to identify and prioritize important MTPs and find the most suitable solutions for the individual resident.

If solutions to MTPs required treatment changes, the residential facility sent a summary of the medication review (prepared by the pharmacist) to the prescriber (the general practitioner and/or the specialist), and subsequently had a dialogue with the prescriber about the medication review results and the implementation of the suggested treatment changes.

If the medication review revealed complex problems, e.g. where multiple prescribers were responsible for the treatment, the residential facility could decide to invite the relevant persons to a "multidisciplinary medicines management conference". The aim of the conference was to involve all the relevant persons in finding common solutions to MTPs.

\section{Data Collection and Analysis}

The formative and explorative nature of the study meant that both quantitative and qualitative data were collected. The outcome measures are described in Table 1. Data on the implementation of the two services were extracted from the audit reports and medication review service documentation forms prepared by the pharmacists for the two services. Data from the medication review service documentation forms completed by the pharmacists were entered into IBM SPSS Statistics version 19 for data analysis.

Data on satisfaction and possible effects of the services were derived through focus group interviews with participating residents, relatives, staff and pharmacists. The interviews were conducted by one of the researchers. One focus group was set up at each of the four facilities, one to two months after study conclusion. The staff members, the pharmacist and the residents were invited to attend. Prescribers and participants unable to participate in the focus groups were offered an individual interview.

\begin{tabular}{|l|l|}
\hline Outcome Measure & Data Source \\
\hline $\begin{array}{l}\text { "Medicines care service" } \\
\text { services" of completed "medicines care }\end{array}$ & $\begin{array}{l}\text { Medication review service } \\
\text { documentation forms }\end{array}$ \\
$\begin{array}{l}\text { Number of MTPs identified at the "medicines } \\
\text { care service". }\end{array}$ & \\
$\begin{array}{l}\text { Type of possible MTPs identified } \\
\text { Suggested solutions to possible MTPs }\end{array}$ & \\
$\begin{array}{l}\text { Number of possible MTPs and solutions sent } \\
\text { to prescribers }\end{array}$ & \\
$\begin{array}{l}\text { Type of possible MTPs and solutions sent to } \\
\text { prescribers } \\
\text { Solutions implemented by prescriber }\end{array}$ & \\
\hline $\begin{array}{l}\text { Quality improvement service } \\
\text { The number of completed quality } \\
\text { improvement services delivered } \\
\text { The number of suggested changes in routines } \\
\text { for handling medicines } \\
\begin{array}{l}\text { The types of suggested changes in routines } \\
\text { for handling medicines }\end{array}\end{array}$ \\
\hline $\begin{array}{l}\text { The combined intervention } \\
\text { prescribers' satisfaction with the intervention }\end{array}$ \\
$\begin{array}{l}\text { Individual interviews } \\
\text { prescribers and persons not }\end{array}$ \\
\hline \\
\hline
\end{tabular}


Page 4 of 8

\begin{tabular}{|l|l|l|}
\hline $\begin{array}{l}\text { Rated changes in staff's knowledge about } \\
\text { medicines }\end{array}$ & $\begin{array}{l}\text { able to participate in focus } \\
\text { group }\end{array}$ \\
$\begin{array}{l}\text { Rated changes in staff's self-efficacy in } \\
\text { relation to safe administration of medicines }\end{array}$ & \\
\hline
\end{tabular}

Table 1: Outcome measures in the study

A semi-structured interview guide was used with questions on satisfaction with the services, benefit for residents and staff, and suggestions for further development of the services. Interviews were recorded, transcribed and commented by participants before analysis. The data analysis was a content analysis where all statements on satisfaction with the intervention and the pharmacy, perceived effects for residents, rated changes in staff s knowledge about medicines and self-efficacy in relation to safe administration of medicines were extracted and categorized under these predefined themes (Table 1).

\section{Results}

\section{The study population}

Table 2 describes the study population at baseline. Only $24 \%$ of all residents living in the four facilities participated in the study. However, the two facilities with up to 100 residents only invited residents from the department where the participating staff worked. The main reason for rejecting participation was residents being anxious about talking to a stranger (Table 2).

\begin{tabular}{|l|l|}
\hline \multicolumn{2}{|l|}{ The study population at baseline } \\
\hline No. of participants & 47 \\
\hline No. of male participants (percentage of total population) & $20(42.6)$ \\
\hline $\begin{array}{l}\text { No. of participants with severe mental illness (percentage of } \\
\text { total population) }\end{array}$ & $17(36.2)$ \\
\hline $\begin{array}{l}\text { No. of participants with physical or intellectual disability } \\
\text { (percentage of total population) }\end{array}$ & $30(63.8)$ \\
\hline $\begin{array}{l}\text { Mean no. of medicines used by each participant on a daily } \\
\text { basis (standard deviation) [range] }\end{array}$ & $\begin{array}{l}5.2 \\
{[1 ; 12]}\end{array}$ \\
\hline $\begin{array}{l}\text { Mean no. of medicines used by each participant as needed } \\
\text { (standard deviation) [range] }\end{array}$ & $2.3(2.0)[0 ; 7]$ \\
\hline
\end{tabular}

Table 2: The study population at baseline

\section{The Quality Improvement Service}

The audit reports contained a total of 45 suggestions for changes in routines for handling medicines mostly concerning the administration of medicines (Table 3). To improve safety and comply with legislation, the pharmacists suggested implementing more documentation and control, developing guidelines, checking medication lists, observing treatment effects and learning from medication errors. There was no systematic follow-up on how the facilities implemented these suggestions [Table 3].

\begin{tabular}{|c|c|}
\hline Stage in the medicines use process & $\begin{array}{c}\text { Suggested changes in } \\
\text { routines (no.) }\end{array}$ \\
\hline Administration of medicines & 19 \\
\hline Ordering of medicines & 7 \\
\hline
\end{tabular}

\begin{tabular}{|c|c|}
\hline Receiving medicines & 5 \\
\hline Storage of medicines & 3 \\
\hline Observation of the effects of medicines use & 3 \\
\hline Disposal of medicines & 3 \\
\hline Guidelines for handling medicines & 3 \\
\hline Documentation of medication errors & 2 \\
\hline
\end{tabular}

Table 3: Community pharmacists' suggested changes in routines for handling medicines at four residential facilities for disabled persons receiving the quality improvement service

\section{Medication Review as a "Medicines Care" Service}

Forty-seven residents received the "medicines care" service (from 6 to 16 residents per facility). On average, the residents used 5.2 $(\mathrm{SD}=3.1)$ [from 1 to 12 ] medicines on a daily basis, and $2.3(\mathrm{SD}=2.0)$ [from 0 to 7] medicines on an as needed basis (Table 2).

The "medicines care" meetings resulted in the identification of 66 MTPs in 30 of the 47 residents. This corresponded to $1.4(\mathrm{SD}=1.4)$ [from 0 to 5] MTPs per resident when including all residents, or 2.2 $(\mathrm{SD}=1.1)$ [from 1 to 5] MTPs per resident when only including residents with at least one MTP. Residents without MTPs used on average $3.8(\mathrm{SD}=2.6)$ [from 1 to 9 ] medicines on a daily basis.

Adverse drug reactions were the most frequent MTPs $(31.8 \%$ of MTPs), followed by improper drug selection and subtherapeutic dosage (each $18.2 \%$ of MTPS) (Table 4). The identified problems mostly concerned treatment for somatic diseases.

\begin{tabular}{|l|c|c|}
\hline \multicolumn{1}{|c|}{ Medication Therapy Problems } & No. & \% of Total No. \\
\hline Adverse drug reactions & 21 & 31.8 \\
\hline Improper drug selection & 12 & 18.2 \\
\hline Sub therapeutic dosage & 12 & 18.2 \\
\hline Inappropriate use of medicines & 7 & 10.6 \\
\hline Untreated indication & 2 & 3.03 \\
\hline Duplicate therapy & 2 & 3.03 \\
\hline Over dosage & 2 & 3.03 \\
\hline Drug use without indication & 2 & 3.03 \\
\hline Miscellaneous & 6 & 9.1 \\
\hline All medication therapy problems & 66 & 100.0 \\
\hline
\end{tabular}

Table 4: Frequency and types of medication therapy problems identified in 47 residents at residential facilities for

disabled persons

The "medicines care" meetings resulted in an agreement on 50 suggestions for solving MTPs in 29 residents (Figure 1). The residential facilities were able to solve 14 MTPs as they did not require involvement of the prescriber. These solutions concerned the use of ointments, the correct use of over-the-counter (OTC) medicines, and 
the implementation of routines for measuring blood pressure or blood glucose.

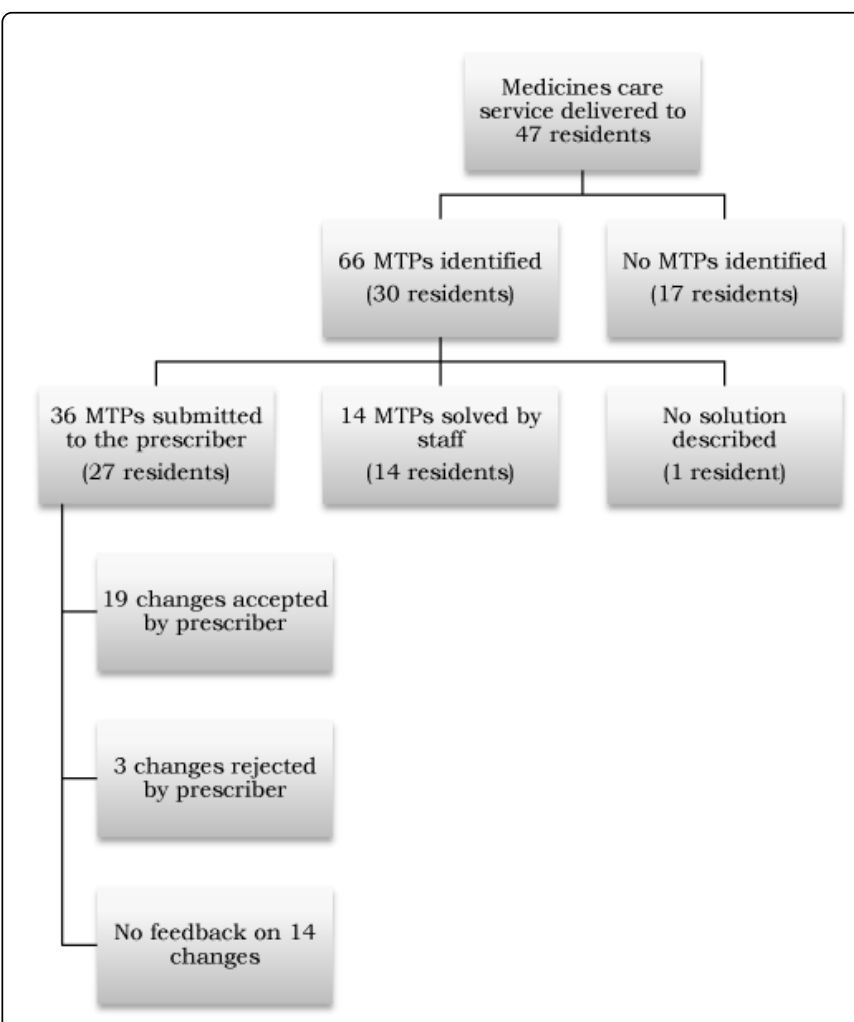

Figure 1: Medication therapy problems and suggested solutions to problems in 47 disabled residents from four residential facilities receiving the "medicines care service"

MTP $=$ Medication therapy problem

For the remaining 27 residents, the prescriber received a summary of the "medicines care" meeting with suggestions for a total of 36 treatment changes. These changes concerned the choice or use of medicines such as discontinuing unnecessary double medication, changing the dosage, switching to a more appropriate treatment, adding medicines, monitoring treatment effect, shifting to more appropriate dosing times, changing drug formulation, switching to a combination treatment or splitting one dosage into two.

The prescribers gave feedback on 22 of the 36 suggestions for solving MTPs (61.1\%). They accepted 19 of the 22 suggestions (86.4\%) and rejected $3(13.6 \%)$.

One "multidisciplinary medicines management conference" was conducted in which the resident, the person responsible for the resident's medicines at the facility, the pharmacist, the general practitioner and the psychiatrist participated.

\section{Satisfaction with and perceived effects of the intervention}

Six interviews were conducted (one parent, two pharmacists, one general practitioner and two specialists). Focus groups were conducted with two to three staff members at each residential facility (including two pharmacists and two residents). Results of the interviews are depicted in Table 5.

The overall impression of the study was positive. All participants felt the intervention was relevant and resulted in positive outcomes. A resident said 'It would be reassuring to have your medicine reviewed by a pharmacist once in a while; after all, we are the ones taking it'. The study strengthened the collaboration between the residential facilities and the community pharmacies, but some facilities found it difficult to get general practitioners involved in discussions about the identified MTPs.

Physicians expressed that they received qualified feedback on their way of practicing. A specialist said: 'It gave me good and constructive input, and was also an opportunity for me to reassess whether my reasons for prescribing the medication was still valid - all for the best of the patient'. The multidisciplinary medicines management conference was deemed productive but unrealistic for every-day practice. Participants expressed that the intervention led to discontinuation of unnecessary medicines and focus on adverse drug reactions.

The quality improvement service led to the pharmacist supporting staff in thinking systematically about medicines and focusing on safety. They felt the service kick-started/supported their own quality improvement work.

\begin{tabular}{|l|l|l|l|l|}
\hline Theme & Staff members & Residents / family & Pharmacists & Physicians \\
\hline $\begin{array}{l}\text { Positive outcomes of the } \\
\text { intervention: }\end{array}$ & $\begin{array}{l}\text { Revelation and articulation of } \\
\text { issues } \\
\text { Check of routines around } \\
\text { medicines } \\
\text { Knowledge and reflections on } \\
\text { medicines } \\
\text { Reassuring with a review of } \\
\text { all the medicines used by a } \\
\text { resident } \\
\text { Focus on medicines } \\
\text { The intervention is needed } \\
\text { Reassuring for staff }\end{array}$ & Reassuring & $\begin{array}{l}\text { An eye-opener to work in the } \\
\text { facilities } \\
\text { Interesting and challenging } \\
\text { work area } \\
\text { Professional marketing of the } \\
\text { pharmacy }\end{array}$ & $\begin{array}{l}\text { Focus on own responsibilities } \\
\text { Prevention of errors } \\
\text { Positive to receive feedback } \\
\text { on own practice } \\
\text { Gave rise to critical review of } \\
\text { responsibilities and practices } \\
\text { Opportunity to reflect on } \\
\text { treatments } \\
\text { onseful for patients }\end{array}$ \\
\hline What to improve & $\begin{array}{l}\text { Follow-up meeting after } \\
\text { project start-up }\end{array}$ & & $\begin{array}{l}\text { More } \\
\text { implementation } \\
\text { intervention in the facility }\end{array}$ \\
\hline
\end{tabular}


Citation: Thomsen LA, Rossing C, Trier H, Faber M, Herborg H (2014) Improving Safety in the Medicines Use Process for Disabled Persons in Residential Facilities. Results from a Pilot Study. J Biosafety Health Educ 2: 114. doi:10.4172/2332-0893.1000114

Page 6 of 8

\begin{tabular}{|c|c|c|c|c|}
\hline & $\begin{array}{l}\text { Cooperation with other } \\
\text { facilities in the study }\end{array}$ & & $\begin{array}{l}\text { Include physicians in the } \\
\text { service }\end{array}$ & \\
\hline $\begin{array}{l}\text { Cooperation with the } \\
\text { pharmacist }\end{array}$ & $\begin{array}{l}\text { Rewarding meetings } \\
\text { Kick-started quality } \\
\text { improvement work that had to } \\
\text { be done anyway } \\
\text { Competent, well-prepared, } \\
\text { curious and humble } \\
\text { Improved cooperation with } \\
\text { the pharmacy } \\
\text { Pharmacy should conduct } \\
\text { yearly medication reviews }\end{array}$ & $\begin{array}{l}\text { Positive to talk about medicines with } \\
\text { a pharmacist } \\
\text { The pharmacist can improve quality }\end{array}$ & & $\begin{array}{l}\text { Relevant input from the } \\
\text { pharmacist }\end{array}$ \\
\hline $\begin{array}{l}\text { Communication between the } \\
\text { facilities and the physicians }\end{array}$ & $\begin{array}{l}\text { Physicians often did not } \\
\text { reflect on input } \\
\text { Physicians wanted to discuss } \\
\text { MTPsb with the resident in } \\
\text { their practice; stressful/an } \\
\text { assault } \\
\text { Physicians were engaged } \\
\text { and generally approved of the } \\
\text { suggestions }\end{array}$ & & $\begin{array}{l}\text { Physicians preferred } \\
\text { communicating with the facility } \\
\text { directly } \\
\text { Started a dialogue between } \\
\text { the facility and physicians } \\
\text { about medicines }\end{array}$ & $\begin{array}{l}\text { Staff better prepared for } \\
\text { consultations } \\
\text { Discussions were at a higher } \\
\text { level; based on facts about } \\
\text { medicines use }\end{array}$ \\
\hline $\begin{array}{l}\text { Staff knowledge about } \\
\text { medicines }\end{array}$ & $\begin{array}{l}\text { More training about diseases, } \\
\text { medicines, ADRsa, ADEsc } \\
\text { and interactions } \\
\text { Less unnecessary worries } \\
\text { about residents' medicines } \\
\text { use }\end{array}$ & & $\begin{array}{l}\text { Great differences in staff } \\
\text { members' knowledge level } \\
\text { Staff now views medicines } \\
\text { more positively } \\
\text { More training of staff about } \\
\text { medicines }\end{array}$ & \\
\hline $\begin{array}{l}\text { Effects of the "medicines care } \\
\text { service" for residents }\end{array}$ & $\begin{array}{l}\text { Discontinuation of medicines } \\
\text { Focus on ADRs }\end{array}$ & Fewer ADRsa & $\begin{array}{l}\text { Discontinuation } \\
\text { unnecessary medicines } \\
\begin{array}{l}\text { Focus on common } \\
\text { overlooked ADRsa }\end{array}\end{array}$ & $\begin{array}{l}\text { Discontinuation } \\
\text { unnecessary medicines }\end{array}$ \\
\hline $\begin{array}{l}\text { Effects of the quality } \\
\text { improvement service }\end{array}$ & $\begin{array}{l}\text { Practical tips } \\
\text { Simple changes } \\
\text { Systematic thinking } \\
\text { Focus on safety } \\
\text { Safer dispensing routines } \\
\text { Suggestions are being } \\
\text { implemented }\end{array}$ & & & \\
\hline
\end{tabular}

Table 5: Results of the interviews and focus groups on satisfaction with and outcomes of the intervention for improving safety in the medicines use process for disabled persons in residential facilities.

$$
\begin{aligned}
& { }^{\mathrm{a}} \mathrm{ADR}=\text { Adverse drug reaction } \\
& { }^{\mathrm{b}} \mathrm{MTP}=\text { medication therapy problem } \\
& { }^{\mathrm{c}} \mathrm{ADE}=\text { adverse drug events }
\end{aligned}
$$

Staff found that the focus on medicines had improved their knowledge and reflections on residents' medicines use. As one staff member said: 'It is a huge responsibility, we can actually kill people if we do something wrong, and we have no training'. Despite their gained knowledge, they requested more training about all aspects of medicines and medicines use. Pharmacists found there were great differences in staff members' knowledge about medicines, and that more training was needed.

\section{Discussion}

The piloted pharmaceutical care services generated an important knowledge of safety issues in the medicines use process for disabled persons living in residential facilities. The services revealed a number of MTPs, the suggested solutions being largely accepted by the residential facilities and the prescribers. The services therefore may have the potential to improve safety. Countries like Other countries have tested and implemented clinical pharmacy services for disabled patients that resulted in identification of MTPs and changes in medication regimens[21,36].

Very few studies have explored the frequency of MTPs in the outpatient disabled population. The rate of MTPs identified in this study is a little lower than the rates identified in studies on elderly $[23,27,37-39]$, and much lower than the 8.2 MTPs per person 
identified in an Australian study on community-dwelling people with mental illnesses [40]. The Australian study used a different categorization of MTPs with a large number of subcategories, which will increase the number of MTPs. Still, we only identified MTPs in less than two thirds of the included patients, whereas MTPs were identified in all patients in the Australian study [40]. A Dutch study on older individuals with intellectual disability found prescribing errors in $47.5 \%$ of the study population; with important risk factors being high age, BMI or frailty index, less severe disability, polypharmacy, and use of medicines acting on the central nervous system[41]. A Danish study on psychiatric inpatients found 189 medication errors in $1,082(17 \%)$ opportunities for errors; $75 \%$ of errors concerned wrong administration of medicines[42].

The outpatient group included in our study was rather inhomogeneous, but patients without MTPs used nearly as many medicines as patients with MTPs. An explanation could be that the pharmacists in our study relied on staff reporting possible symptoms of MTPs. If staff were unaware of such symptoms, they may have been overlooked. If pharmacists had interviewed patients as in the Australian study, they might have identified more problems. Also, the pharmacists might have overlooked MTPs. Future studies should focus on the validity of pharmacists' identification of MTPs in people with disabilities, and on developing tools which may assist staff in selecting the right patients for the "medicines care" service.

Staff in residential facilities often plays a central role in monitoring medical treatment and informing healthcare professionals about possible negative outcomes. This requires knowledge about medicines, a knowledge that staff without health care training do not always feel they possess. Studies conducted in nursing homes have shown that educational activities and active participation in the medicines use process through services similar to those tested in this study improve staffs' self-efficacy in taking responsibility for administering medicines to the elderly $[27,30,43]$. Results from this study indicate that staff's knowledge and self-efficacy increased, but this has to be confirmed in a larger study with objective measurement thereof.

The quality improvement service resulted in the facility receiving an audit report with a number of relevant suggestions for improved handling of medicines. Particularly, the pharmacist supported staff in thinking systematically about medicines and focusing on safety. We received limited information on how the facilities used the quality improvement service to generate safer workflows, and this needs further investigation in future studies.

The "multidisciplinary medicines management conference" was perceived as effective and rewarding, but not possible to organize in every day practice. Other more feasible solutions may be investigated, for example whether it is possible to organize tele- or webconferences.

\section{Limitations of the study}

This study was a pilot study with only four residential facilities and 47 residents with varying disabilities and needs. The participating residents do not necessarily represent the disabled population in residential facilities in general, and other residential facilities may have different routines for handling medicines. Also, the effects of the intervention on staff's knowledge and self-efficacy and residents' medicines use were not formally measured, and results therefore need to be validated in a larger trial with the appropriate design. The research group has subsequently initiated two studies. The first study tests a community pharmacy-led, individually tailored educational programme on safe medication practices for staff in residential facilities without healthcare training. The second study aims at achieving a safer use of medicines through staff's participation in an educational programme followed by the development and implementation of safer workflows using the model for improvement as a framework [44].

\section{Conclusions}

The study demonstrated that there is a need for improved safety in the medicines use process for disabled persons in residential facilities. The piloted pharmaceutical care services generated important knowledge of safety issues and revealed a number of MTPs, the suggested solutions being largely accepted by the residential facilities and the prescribers. The developed services were implementable in practice and demonstrated a potential to improve safety. A larger prospective trial is needed to confirm the effects of the intervention.

\section{Conflicts of interests}

None

\section{References}

1. United Nations (2006) Convention on the Rights of Persons with Disabilities.

2. Gulley SP, Altman BM (2008) Disability in two health care systems: access, quality, satisfaction, and physician contacts among working-age Canadians and Americans with disabilities. Disabil Health J. 1:196-208.

3. Hassiotis A, Turk J (2012) Mental health needs in adolescents with intellectual disabilities: cross-sectional survey of a service sample. J Appl Res Intellect Disabil 25: 252-261.

4. Lewis MA, Lewis CE, Leake B, King BH, Lindemann R (2002) The quality of health care for adults with developmental disabilities. Public Health Rep 117: 174-184.

5. Krahn GL, Hammond L, Turner A (2006) A cascade of disparities; Health and health care access for people with intellectual disabilities. Ment Retard Dev Disabil Res Rev 12: 70-82.

6. Statbank Denmark (2013) Statistics Denmark.

7. The Danish Mental Health Foundation (2013).

8. de Winter CF, Bastiaanse LP, Hilgenkamp TI, Evenhuis HM, Echfeld MA (2012) Overweight and obesity in older people with intellectual disability. Res Dev Disabil 33: 398-405.

9. Torr J, Davis R (2007) Ageing and mental health problems in people with intellectual disability. Curr Opin Psychiatry 20: 467-471.

10. Heald A (2010) Physical health in schizophrenia: a challenge for antipsychotic therapy. Eur Psychiatry 25 Suppl 2: S6-11.

11. Henman M (2011) The Professional and Personal Challenge of Intellectual Disability. Presentation at the European Society for Clinical Pharmacy (ESCP) Symposium. Dublin.

12. Ramian K (2009) Medicin i socialpsykiatriske botilbud. Mellem medicinhåndtering og medicinpædagogik. Conclusive report. Århus: Center for quality development, Region Midtjylland.

13. Aronson JK (2009) Medication errors: definitions and classification. Br J Clin Pharmacol 67: 599-604.

14. Embedslægerne og tilsyn. Tilsynstema (2010) Behandling med antipsykotiske lægemidler på bosteder og plejeboliger. Copenhagen: Danish Health and Medicines Authority.

15. Baandrup L (2009) Antipsychotic polyfarmaci: Exploring the gap between evidence and practise. $\mathrm{PhD}$ thesis. University of Copenhagen: Faculty of Health Sciences. 
Citation: Thomsen LA, Rossing C, Trier H, Faber M, Herborg H (2014) Improving Safety in the Medicines Use Process for Disabled Persons in Residential Facilities. Results from a Pilot Study. J Biosafety Health Educ 2: 114. doi:10.4172/2332-0893.1000114

Page 8 of 8

16. Robertson J, Emerson E, Gregory N, Hatton C, Kessissoglou S, et al. (2000) Receipt of psychotropic medication by people with intellectua disability in residential settings. J Intellect Disabil Res 44: 666-676.

17. Matson JL, Neal D (2009) Psychotropic medication use for challenging behaviours in persons with intellectual disabilities: an overview. Res Dev Disabil 30: 572-586.

18. van den Bemt PM, Robertz R, de Jong AL, van Roon EN, Leufkens HG (2007) Drug administration errors in an institution for individuals with intellectual disability: an observational study. J Intellect Disabil Res 51: 528-536.

19. Laursen TM, Munk-Olsen T, Nordentoft M, Mortensen PB (2007) Increased mortality among patients admitted with major psychiatric disorders: a register-based study comparing mortality in unipolar depressive disorder, bipolar affective disorder, schizoaffective disorder, and schizophrenia. J Clin Psychiatry 68:899-907.

20. Wahlbeck K, Westman J, Nordentoft M, Gissler M, Laursen TM (2011) Outcomes of Nordic mental health systems: life expectancy of patients with mental disorders. Br J Psychiatry 199: 453-458.

21. Bell S, McLachlan AJ, Aslani P, Whitehead P, Chen TF (2005) Community pharmacy services to optimise the use of medications for mental illness: a systematic review. Aust New Zealand Health Policy 2: PMC1345690.

22. Herborg H, Søndergaard B, Frøkjær B, Fonnesbaek L, Jørgensen T, et al. (2001) Improving drug therapy for patients with asthma - part 1 and part 2. J Am Pharm Assoc 41: 539-559.

23. Bernsten C, Björkman I, Caramona M, Crealey G, Frøkjær B, et al. (2001) Improving the well-Being of elderly patients via community pharmacybased provision of pharmaceutical care. Multicentre study in seven European countries. Drugs Aging 18: 63-77.

24. Dinsen C, Kirkeby B, Herborg H, Kjellberg J, Stæhr P, et al. (2004) Klinisk farmaceut i primærsektoren. Hillerød: Frederiksborg Amt.

25. Dam P, Herborg H, Rossing C, Sørensen L (2007) Sikker og effektiv medicinbrug for brugere af blodtryksmedicin. Hillerød: Pharmakon.

26. Dam P, Herborg H, Rossing C, Pultz K, Sørensen L (2007) Sikker og effektiv medicinbrug for type 2-diabetikere. Hillerød: Pharmakon.

27. Rossing C, El-Souri M, Herborg H, Pultz K, Thomsen LA (2010) Bedre brug af medicin i hjemmepleje og på plejehjem. Et udviklings- og pilotprojekt for en kontrolleret undersøgelse. Hillerød: Pharmakon.

28. Rossing C, Agergaard M, El-Souri M, Pultz K (2010) Evaluering af medicingennemgang med compliancerettet rådgivning - en rådgivningsydelse til hjertepatienter. Hillerød: Pharmakon.

29. Dam P, Herborg H, Pultz K, Rossing C, Thomsen LA (2011) Sikker og effektiv medicinbrug for type 2-diabetikere. Færdigudvikling og evaluering af en regionalt forankret model. Hillerød: Pharmakon.

30. El Souri M, Pultz K, Rossing C (2012) Bedre medicinanvendelse på plejehjem. [Better use of medicines in nursing homes. An implementation study]. Hillerød: Pharmakon.
31. Craig P, Dieppe P, Macintyre S, Michie S, Nazareth I, et al. (2008) Developing and evaluating complex interventions: new guidance. Medical Research Council. 2008.

32. Cipolle R, Strand L, Morley P (2004) Pharmaceutical care practice. The clinician's guide. Second ed. Medical Publishing Division, USA.

33. Hepler CD, Segal R (2003) Preventing medication errors and improving drug therapy outcomes. A mangement systems approach. First ed. Washington DC: CRC Press.

34. Nimmo CM (2000) Developing training materials and programs: creating educational objectives and assessing their attainment. In: Nimmo CM, Guerrero R, Greene SA, Taylor JT, editors. Staff development for pharmacy practice. Bethesda: ASHP 109-119.

35. Strand LM, Morley P, Cipolle RJ, Ramsey R, Lamsam GD (1990) Drugrelated problems: their structure and function. DICP Ann Pharmacother 24: 1093-1097.

36. Chrischilles EA, Doucette W, Farris K, Lindgren S, Gryzlak B, et al. (2014) Medication therapy management and complex patients with disabiltiy: a randomized controlled trial. Ann Pharmacother 48:158-167.

37. Elliott RA, Martinac G, Campbell S, Thorn J, Woodward MC (2012) Pharmacist-led medication review to identify medication-related problems in older people referred to an Aged Care Assessment Team: a randomized comparative study. Drugs Ageing 29: 593-605.

38. Milos V, Rekman E, Bondesson Å, Eriksson T, Jakobsson U, et al. (2013) Improving the quality of pharmacotherapy in elderly patients through medication reviews: a randomised controlled study. Drugs Ageing 30:235-246.

39. Kaur S, Roberts JA, Roberts MS (2012) Evaluation of medication-related problems in medication reviews: a comparative perspective. Ann Pharmacother 46: 972-982.

40. Bell JS, Whitehead P, Aslani P, McLachlan AJ, Chen TF (2006) Drugrelated problems in the community setting - Pharmacists' findings and recommendations for people with mental illnesses. Clin Drug Invest 26: 415-425.

41. Zaal RJ, van der Kaaij AD, Evenhuis HM, van den Bemt PM (2013) Prescription errors in older individuals with an intellectual disability: prevalence and risk factors in the Healthy Ageing and Intellectual Disability Study. Res Dev Disabil 34:1656-1662.

42. Soerensen AL, Lisby M, Nielsen LP, Poulsen BK, Jan Mainz, et al. (2013) The medication process in a psychiatric hospital: are errors a potential threat to patient safety? Risk Manag Healthc Policy 6: 23-31.

43. Arnetz JE, Hasson H (2007) Evaluation of an educational "toolbox" for improving nursing staff competence and psychosocial work environment in elderly care: Results of a prospective, non-randomized controlled intervention. Int J Nurs Stud 44: 723-735.

44. Langley GL, Nolan KM, Nolan TW, Norman CL, Provost LP (2009) The Improvement Guide: A Practical Approach to Enhancing Organizational Performance. 2 ed. San Francisco: Jossey-Bass Publishers, USA. 